\title{
Qualitative research in social and organizational psychology: the Italian way
}

\section{Introduction}

Our paper provides a mapping of qualitative research in social and organizational psychology. This mapping was directed by the authors' choices and this means that scholars from other perspectives are likely to offer different readings of the same topic. The first choice was to not consider the clinical and developmental psychological research, so to deepen our exploration of the two areas in which we work on, and on which we have a more articulated perspective. These two areas differ for some aspects, but they also present some relevant common elements, as it is demonstrated by the fact that scholars working in social and organizational psychology are part of the same academic recruitment field (“11/E3 Social psychology and work and organizational psychology”).

The first section of the article consists of a short history of qualitative research in Italian psychology. To deepen the focus on the most recent developments, in the second section we present a review of the scientific articles published in the last five years.

\section{Section 1: An historical framework}

Our historical framework is articulated in three phases: the beginnings (1990-2000), the diffusion (2001-2010), and the current quasi-institutionalisation phase.

\subsection{The beginnings}

We consider the role of two main factors that characterize this initial phase. The first is the slow but constant legitimisation of qualitative research in sociology (Bruni \& Gobo 2005); the second is the emergence of theoretical perspectives expressing a critical stance towards the hegemonic quantitative and experimental approach of the discipline. A third factor, which concerns organizational psychology, is the demand from public and private clients for qualitative studies, which, until then, had been mainly conducted in non-academic fields. In the rest of the paragraph, we discuss these three factors.

Regarding the first factor, we note that the methodological reflection on qualitative research in the Italian academic context was originally developed in sociology, similar to what happened at the international level (Kidd 2002). The book by Ferrarotti (1989) and the conference on qualitative methods organised in 1993 by Cipolla and de Lillo greatly stimulated the debate on this topic. In 
that same period, new sociological texts on qualitative research were published (Ricolfi 1997; Losito 1998). The influence of the sociological debate is visible in two major books on qualitative methodologies in social psychology. In the first, the author starts from the distinction proposed by Guba and Lincoln between the qualitative and quantitative paradigms (Mannetti 1998). In the second one, the author underlines the contribution of Grounded Theory, Ethnomethodology, Conversation analysis and Symbolic interactionism to the foundations of psychological qualitative research (Mazzara 2002).

Regarding the second factor, we refer to Grounded Theory and discourse analysis, as we explain below.

Grounded theory's influence is well represented by the participatory action studies on cities conducted in the 1990s by Arcidiacono with Heiner Legewie, a student of Glaser and Strauss (Arcidiacono 2004). The grounded theory approach allowed to inductively access the world of people with/for whom research is conducted and to analyse the data from their perspective. These characteristics of Grounded theory express a critique toward the hegemonic model in psychology, which is based on a deductive approach and that attributes a passive role to the subject.

Concerning discourse analysis, we refer to a variety of approaches whose common characteristic is that discourse is studied as the code through which meanings are recognised, negotiated, and changed (Bonaiuto \& Fasulo 1998). This choice is linked to a critique of the prevailing individualistic orientation of the discipline (Bellelli 1989), in favour of an appreciation of the cultural dimension of psychological processes (Mantovani 1998). The analysis of discourses aims to understand these processes with an ecological approach that reveals their contextual nature (Zucchermaglio 1991). In this approach, the individual is no longer (only) the one who makes mistakes and uses cognitive shortcuts, as in the model of social cognition. She/he is an active subject engaged in meaning-making activities with others (Zucchermaglio 2000) in a network of ideological influences and collective memories that can be explored thorough the analysis of discursive productions (Colucci \& Camussi 1998). In this literature, the authors mainly refer to rhetorical psychology (Billig 1991) and discursive psychology (Edwards \& Potter 1992).

Interest in the transformative impact of qualitative research and the critique of "non-ecological" quantitative research also characterised organizational psychology. In this context, the book by Piccardo \& Benozzo (1996) contributed both to the diffusion of ethnography in Italy and to the legitimation of qualitative methods. That testifies to the influence of two traditions: the cultural anthropology and the psychosociological approach, developed in England (Jaques 1951) and France (Kaës 1968). French psychosociology is also the theoretical framework of action research studies 
conducted in private and public companies by Kaneklin and his collaborators (1990). These studies use ethnographic and narrative methods, and a grounded theory approach, highlighting the usefulness of qualitative research for consultancy activities promoting individual, group and organizational change and development.

Finally, the third factor that explains the genesis of qualitative research in Italy mainly concerns organizational psychology and consumer psychology. The marketing field and the investigation of consumer experience were the most important areas in which researchers began to use qualitative research, such as in health and evaluation research. These methods allow for the exploration of the client's needs and the contextual and social conditions of the demand for goods and services (Bosio 1992). They also fit the objective of evaluating services and the quality of organizational processes, considering symbolic and cultural dimensions.

\subsection{Diffusion}

The number of books on qualitative research in psychology published in the first decade of 2000 testifies its rise. These books present different qualitative approaches (Cicognani 2002; Lucidi, Alivernini \& Pedon 2008) or specific methods, such as interviews and focus groups (Zammuner 2003; Albanesi 2004). In the literature on qualitative data analysis, special attention is paid to computer programs (Chiarolanza \& Di Gregorio 2007; Colucci \& Montali 2008), while there is no discussion of methods that valorise the interpretative activity of the researcher, such as thematic analysis (Braun \& Clarke 2005), or interpretative phenomenological analysis (Smith \& Osborn 2004). Nevertheless, this tendency does not seem homogeneous, as evidenced by the attention dedicated to discursive social psychology (De Grada \& Bonaiuto 2002) and to qualitative action research methodologies (Colucci, Colombo \& Montali 2008), as well as by the methodological reflection and research in the field of cultural psychology and community psychology (Zucchermaglio 2002). In the discursive theoretical framework, the focus is on the study of discourse as a daily practice (Mininni 2003), which depends on the cooperation of others, who are co-authors for the meanings constructed in the interaction (Mantovani 2008).

With regard to community psychology, grounded theory remains the main theoretical and methodological model. This is the case, for example, in qualitative studies that address issues regarding the sense of community (Mannarini \& Fedi 2009) or corporate social responsibility (D'Aprile \& Mannarini 2010).

In the 2000s, the methodological and epistemological literature also developed in organizational psychology. Within a constructivist framework, Bosio (2000) proposed an idea of multiparadigmatic and multi-theoretical research. The challenges were, on the one hand, to mark a 
distance from neo-positivist approaches by reformulating paradigmatic, theoretical and methodological assumptions and, on the other, to pay attention to the new technologies for data collection and analysis (Bosio, Graffigna \& Olson 2007). Within this framework, two main methodological approaches have proven their worth. The first is the development of the ethnographic and narrative researches concerning the evaluation of services/quality. These studies partly reflected the positions of organizational sociology (Nicolini, Gherardi \& Yanow 2003) and partly followed the cultural psychology studies on organisations (Scaratti \& Regalia 2000). The second is the action research approach (Kanenlin 2006), which focuses on the role of research and researchers as catalysts for knowledge production processes and organizational change.

From the second decade of the year 2000, there has been a growing critical psychology literature concerning the study of organisations and management. Some epistemological reflections highlight, for example, the need for research that resists the neo-positivist "mainstream" and that establishes itself through its social relevance (Scaratti et al. 2014). These reflections are supported by studies that used critical discourse analysis (Pizzorno, Benozzo \& Carey 2015), or unconventional approaches (Benozzo, Koro-Ljungberg \& Carey 2015).

\subsection{The (quasi) institutionalisation}

A process of quasi-institutionalisation characterises the actual situation. Compared to previous years, a growing number of Italian scholars publish qualitative researches in international journals. The variety of journals and research themes indicate that qualitative research is not confined to a few areas (see Section 2). Articles presenting qualitative research are also a non-marginal portion of the most important Italian journals for this field: Psicologia sociale, Psicologia di Comunità, Psicologia della salute, Studi Organizzativi.

This growth process is encouraged by the fact that many universities offer training in qualitative research in psychology (Bosio \& Graffigna 2007).

Nevertheless, the process of institutionalisation has some limitations. For example, training initiatives organised by the Italian Association of Psychology have been reduced over time and are now interrupted. Moreover, no qualitative research project has ever obtained the funds provided under the National Research Projects of the Ministry of the University, which constitute the most important source of funding in Italy.

This situation is explored in more details in the following section. 


\section{Section 2: The Current Status of QR in Social and Organizational Psychology in Italy}

\subsection{Method}

From the Scopus database, we extracted the articles published from 2013 to 2018 by the 171 professors and researchers in social psychology (n. 93) and organizational psychology (n. 78) who are included in the official list of the Italian Ministry for the University. The choice of a five-year period is due to two main reasons. First, we intended to analyse the more recent developments in social and organizational qualitative psychology. Second, during this period a relevant change occurred in the mechanism that rules the Italian academic careers. In 2012, a new procedure called 'National scientific abilitation' became operative. It consists in an evaluation of the production of each candidate who wants to apply for a new position or an advancement in his/her academic career. This evaluation rewards the production of articles indexed on international databases, such as the one we use, while 'devaluing' other products, such as books or articles in national journals that are typically not indexed. This explains why we choose this temporal span, in which this scientific production has surely increased. We may also note that the choice of a five-year period for a review literature is not uncommon (Saks \& Ashforth 1997; Jessel \& Ingvarsson 2016).

We then screened the articles for their fit with this publication's goal. We did not include quantitative and mixed-method designs; reviews and overviews of books or investigations; editorials; books and book chapters; conference proceedings; and theoretical papers that were not related to research methodologies. As a result, we selected 179 articles in social psychology and 86 in organizational psychology.

We then analysed the abstracts to identify the study's main topics, objectives, and the methodologies of data collection and analysis. Relying on abstract for reviews is a common practice (Kressel \& Kressel 2016). In addition, when the abstract did not provide all the necessary information, we read the entire article to get a clear understanding of the research's perspective and methods. In the following section, we provide an overview of these themes and methods. We also provide some references that readers may find useful to further explore these areas. We realize that, in naming some authors, we run the risk of excluding others, but space limitations prevented us from being able to list all of the researchers.

\subsection{Qualitative Social Psychology}


We identified six areas of research that concern health, environment, politics, immigration and national identity, gender and sexual identity, and family (Table 1). We present them below.

\section{INSERT TABLE 1}

"Health" is a main area of investigation that includes a number of sub-topics. In particular, scholars have researched patients' illness experiences (Zucchermaglio \& Alby 2017) and engagement in diagnostic and treatment processes (Mazzoni, Cornet, van Leeuw, Myllys \& Cicognani 2018). Studies in health psychology have focused mainly on the analysis of individual behaviour or thoughts. Fewer studies analysed dyadic interactions concerning patient-doctor communications (Fatigante, Alby, Zucchermaglio \& Baruzzo 2016) or social constructions of illnesses and health dimensions. The latter consider specifically the contribution of cultural resources and contextual aspects in articulating health issues, taking a social representations framework (Nencini, Sarrica, Cancian \& Contarello 2014) or a post-structural approach (Frigerio, Montali \& Fine 2013; Frigerio \& Montali 2016). In the area of health psychology, we found the widest range of methods of research, from individual interviews to observation of naturally occurring interactions (Alby, Zucchermaglio \& Baruzzo 2015). Regarding data analysis, interviews were prevalently analysed through thematic analysis or interpretative phenomenological analysis. Differently, studies aimed at a better understanding of communication practices between patients and doctors have used conversation and discourse analyses. In this research area, "Dial-textual analysis" (Manuti, Scardigno \& Mininni 2017) stood out as an innovative method for semiotic data analysis.

In the "Environment" area, qualitative studies mostly concerned human-environment interactions (Sarrica, Roseti, Brondi, Cervelli \& Leone 2016), stakeholder positioning (Prati, Albanesi, Pietrantoni \& Airoldi 2016) and social representations of climate change and sustainable energy (Brondi, Sarrica, Caramis, Piccolo \& Mazzara 2016). The overall goal of these studies was to understand public views on environmental issues and to provide clues for more effective practices and communication campaigns. In this area, visual and multimedia methods are sometimes adopted (de Rosa, Bocci \& Dryjanska 2017), and content or descriptive analyses, such as thematic analysis, prevailed.

With regard to "Politics", Italian scholars have mainly researched citizen identity and citizenship (Marzana, Fasanelli, Mercuri \& Fattori 2016), as well as social activism and citizens' political participation (Mazzoni \& Cicognani, 2013; Mannarini \& Fedi 2012). Related to this area, researchers analysed media campaigns and representations of sensitive issues, such as the economic crisis (Rizzoli, Romaioli \& Contarello 2017). This topic is mostly associated to community and cultural psychology approaches: scholars largely adopted critical psychology perspectives and 
participatory methods, to promote inclusive processes and engagement in collective action (Arcidiacono, Grimaldi, Di Martino \& Procentese 2016). In-depth interviews, video, photos, and observation were used to provide rich and interactive data useful for action and intervention. Analyses of political speeches were among the most common research strategies (Pola, Sarrica \& Contarello 2015). Concerning data analysis, multimodal analysis of communication represented an original approach (Leone, Di Murro \& Crescenzi 2015).

The topic "Immigration and national identity" comprises researches concerning prejudice, discrimination, immigration, and the progressive diversification of society (Gattino \& Miglietta 2013; Mannarini \& Procentese 2018). While still being a country from which many younger people emigrate, Italy has recently become a country of immigration. As new communities develop, the psychological sense of community has been an important topic of qualitative research (Barbieri, Zani \& Sonn 2014; Mannarini \& Rochira 2014). Qualitative research in this field shows an array of qualitative methods. Most common were different interview styles and the use of archives (Montali, Riva, Frigerio \& Mele 2013), together with photovoice and observation (Rania, Migliorini, Rebora \& Cardinali 2015; Zamperini \& Mascena 2017), which were analyzed through grounded theory, thematic, conversation and content analysis. When research questions concerned broad and contextbased topics, researchers adopted a variety of methods. For instance, in a research involving local and immigrant communities, Arcidiacono and her colleagues based their work on data coming from in-depth interviews, focus groups and observations (Arcidiacono, Natale, Carbone \& Procentese 2017).

In the "Gender and sexual identities" research area, most studies focused on transgenderism (Hochdorn, Faleiros, Camargo \& Cottone 2016) and gender-based discrimination (Fedi, Colombo, Bertola \& Rollero 2017), mainly through interviews and the analysis of media advertising and diaries. Constructionist approaches were common in this area, especially in light of the relevance that language, social interpretations, and power-based relations have to define this field (De Simone, Lasio, Onnis \& Putzu 2017).

"Family functioning and interventions" were mostly investigated through interviews and focus groups as well as ecological strategies for data collection, such as video-recording of naturally occurring interactions (Everri, Fruggeri \& Molinari 2014) or the analysis of autobiographical memories in family narratives. In addition to the common use of thematic analysis and grounded theory, discourse and narrative analyses (Zamperini, Testoni, Primo, Prandelli \& Monti 2016) were adopted to analyze the data. 
We conclude with some methodological remarks about relevant absences in our data. Concerning data collection methods, we note that visual methods were barely adopted. Another peculiar aspect is the scarcity of longitudinal approaches that could address dynamics and change: diaries and cultural resources, such as mass-media and books were barely used as data collection sources. Concerning data analysis, we observe that many studies lacked transparency. For instance, in numerous articles, the process of analysis was not described beyond a reference to having "used a software to analyze the data". Phenomenological Analysis was not as common as we would have expected despite the embeddedness of research area in processes of interpretation and the lived experiences of migrants and citizens. For instance, only one study used IPA (Testoni, Ghellar, Rodelli, De Cataldo \& Zamperini 2017). Similarly, just a few publications adopted critical approaches, whether based on Critical Theory or feminist or post-structural theories (Manuti, Scardigno \&Mininni 2017)

\subsection{Qualitative Organizational Psychology}

We identified three main research topics: health, gender and sexual identity, and dynamics of organizational life (Table 2).

\section{INSERT TABLE 2}

"Health" is the most researched topic, with two foci. The first is on patient's engagement and it concerns the analysis of the patient-doctor relationship and the client's involvement in the service as a factor that influences his/her satisfaction regarding health services (Gilardi, Guglielmetti, Casati \& Monti 2014; Barello \& Graffigna 2015; Menichetti \& Graffigna 2016). The second focus regards the analysis of the healthcare sector's organisations, with the aim of increasing organizational efficiency. Studies concern the analysis of work practice(s) (Gilardi, Guglielmetti \& Pravettoni 2014) and workers' resources, in a context characterised by corporatisation of the hospitals and a demand for a higher quality of services (Gozzoli, Gazzaroli \& D'Angelo 2018). Other studies investigate the impact of technological innovation on the quality of healthcare service (Liberati, Gorli, Moja, Galuppo, Ripamonti \& Scaratti 2015) and on diagnostic decisions (Panari et al. 2015).

Regarding data collection, the use of the interview prevails, either with patients or with health workers. Approximately half of the studies use more than one method, for example diaries and interviews or observations and analysis of documents, to understand the complexity of the problems and the different stakeholders' perspectives. The use of methods that allow a longitudinal analysis 
of phenomena, such as narrative diary or observation of practices, prevails only in those studies that investigate the theme of health from an organizational point of view.

As for data analysis, in line with the exploratory nature of many of the researches in this area, we observe the prevalence of thematic analysis and qualitative content analysis. Grounded Theory is more frequent in studies that aim at favouring patients' and healthcare providers' engagement, as a method that allows to fully appreciate their points of views, promoting their activation. Finally, we observe that some studies do not indicate the data analysis procedure.

Within the area of "Gender and sexual identity", we identified three lines of research. A first line is centered on the gender gap and equal opportunities in different contexts, from the political scene to care professions and healthcare. A second line concerns gender identity construction and career development from a gender perspective (Pizzorno, Benozzo, Fina, Sabato \& Scopesi 2014). A third line of work revolves around sexual identity construction. We can identify two main foci. The first concerns how some organizations manage the inclusion of LGBT workers and how organizations can value (sexual) identity diversity (De Simone \& Scano 2017). The second focus concerns sexual identity disclosure (Benozzo 2013; Benozzo, Pizzorno, Bell \& Koro-Ljungberg 2015). A constructivist and/or poststructuralist approach generally informed the studies on gender and sexual identity. Data analysis mostly utilizes de-constructivist techniques such as Critical Discourse Analysis (Fairclough 2001) applied to data collected retrieved through narrative and biographical interviews

The research topic "Dynamics of organizational life" concerns three sub-topics: organizational change, well-being, and emerging difficulties of work and organization.

Under the label Organizational change, we comprised researches concerning how work practices and professional identity are changing in different contexts (D'Angelo, Reverberi, Gazzaroli \& Gozzoli 2017), the issue of organizational authorship (Ripamonti, Galuppo, Gorli, Scaratti \& Cunliffe 2015) and the impact of new technologies on working groups (Ripamonti \& Galuppo 2016).

For what concerns the well-being area, research address organizational membership (Bruno \& Dell'Aversana 2018), and mediation and conflict (Tamanza, Gozzoli \& Gennari 2016). In the subtopic concerning emerging difficulties of work and organization we grouped studies concerning marginalization and precariousness (Di Fabio, 2016), adolescents' work (Benevene, Cortini \& Di Lemma 2014) and migrant inequalities. A promising area of research regards legality and taxation in an IPA perspective (Castiglioni, Lozza \& Bosio 2018; Lozza, Cinelli \& De Rosa 2017) 
From an epistemological point of view, research on "Dynamics of organizational life" are characterized by a vision of the subject as an active constructor of her/his organizational contexts, who holds a local and specific knowledge and has a capacity of self-reflection on her/his actions. This assumption supports the use of data collection methods such as shadowing, "collecting of managerial situated competence" and "interview to the double" which are specific to this area of research. These methods are based on cooperative processes that involve both researchers and participants and that are aimed at getting closer to the participants' knowledge and experience. It is also interesting to observe that the interview is, in its many variations (biographical, narrative, indepth, to the double) the most used method to study organizational change and to promote it. Finally, within this area we also found the use of reflexive methods for data collection and analysis. With the expression "reflexive methods" (Ripamonti, Galuppo, Bruno, Ivaldi \& Scaratti 2018) we refer to contexts in which the participants are invited to think retrospectively to their work experience and to the reasons behind their organizational actions.

\section{Discussion}

The analysis of the abstracts allowed us to identify the most relevant research areas in the two disciplinary fields and to compare them. The health field stands out as the one with the greatest number of publications, both for social and organizational psychology. For this, we propose two possible explanations. The first refers to a representation of psychology as a discipline that, despite its variety, is concerned with improving people's health and well-being. A confirmation of this reading is that the Italian law regulating mental health professions, approved in 2017, has included them in the general category of health professions, as requested by the professional body of psychologists. The second possible explanation deals with the rules that regulates the academic careers in Italy. Since 2012, researchers are required to publish numerous articles in high-impact journals in order to apply for permanent positions or advancement in their career. Doing research in the health field offers an advantage: the scientific journals in this area are much more than those that focus on psychology and they generally have a higher impact factor.

Regarding the topic of gender issues, our data underline a difference between social psychology and organizational psychology. In the former, gender turns out to be, together with health, the most important area of research, while in organizational psychology the amount of publications is more limited. This can be better understood if one considers, for instance that Italy is one of the European countries with the lowest percentage of working women and one of the greatest difference in salary between men and women (World Economic Forum 2017). In this context, it can also be observed 
that Italian companies usually pay marginal attention to the topic of diversity, although this concern is present in the general society and in international companies based in Italy.

Regarding the data collection methods, the prevalence of the interview emerges from our analysis. This feature characterizes also international qualitative psychology, so that some authors have written about an excessive use of this tool (Potter \& Hepburn 2005.). One possible explanation is that the interview is considered the fundamental tool for every psychologist, who acquires it during her/his training and professional practice. The use of the clinical and the research interview is indeed based on the belief that these methods allow to access the "internal" world of the speakers, identifying meanings, relevant experiences and the contexts in which they are created.

In comparison to the interview, we observed a limited use of focus groups. This data can be considered an indicator of the difficulty to abandon an individual-oriented perspective, even in studies regarding groups and organizations or in research areas that are explicitly relational and context-based, such as identity, family and politics. An exception is constituted by community psychology, cultural psychology, and a relevant part of organizational psychology in which, coherently with the epistemological perspectives adopted, participatory research methods such as photovoice, the use of participant observation, the collection of discursive productions in natural settings, and the study of archival data tend to be prominent.

As far as data analysis is concerned, a significant proportion of the abstracts did not mention the model that was followed or the analysis procedures. Since these articles are published in international journals, this is a modality of presentation of the research accepted by these journals. More generally, it emerges that, although articulate, in the abstracts there are three prevailing methodologies: Grounded Theory, discourse analysis, and Conversation analysis. Alongside these methodologies, stands a large field of semantic analysis, from thematic to content analysis, none of which has established itself as a standard. Moreover, there are many analytical practices that call themselves qualitative and that consist of a summary of the analysed contents, as in many cases emerged by the reading of the articles.

\section{Conclusions}

In the article, we have identified three phases of the development of qualitative research in Italian social and organizational psychology. These three phases trace a path beginning in the 90s and that, through a gradual process of communication and popularization, led to the current quasiinstitutionalisation of qualitative methodologies. In this context, we highlighted two factors that 
influenced the initial phases of psychological qualitative research: the methodological debate in sociology and the critical approaches contesting the dominant individualistic, experimental, and quantitative frameworks of the discipline. These two factors have characterized the development of qualitative research also at the international level (Denzin \& Lincoln 1994), which is not surprising, considering that the scientific community is increasingly globalized. A third aspect, which particularly concerned organizational psychology, was the demand for qualitative research that came from public and private clients/organizations. This demand required a change of scientific practices as a response to the requests of companies and institutions.

A growing number of publications and scientific initiatives shows the diffusion of qualitative research in psychology from the 2000s. In this phase, we noticed the effort, in particular in the fields of community, cultural and organizational psychology to connect qualitative research to theories concerned with the transformative impact of research and the enhancement of the cultural and contextual nature of the psychological processes.

The current phase of quasi-institutionalisation is characterized by two contrasting tendencies. On the one hand, we observe the growth of qualitative psychological researches, which confirm its legitimization. On the other hand, this methodology continues to occupy, in terms of funding and active researchers, marginal positions.

Our analysis indicates that the literature that we analysed seems to be short of innovation from a methodological point of view. For example, while at the international level an increasing attention is paid to methods like memory work (Stephenson \& Kippax 2008), art-based research (Chamberlain et al. 2018) and the diary method (Bolger, Davis \& Rafaeli 2003) these approaches are absent in our database. Qualitative research on social media, which is an important emerging sector, also appears marginal in our country. Furthermore, one can observe how some perspectives, such as postqualitative research (St. Pierre 2018), still have a marginal influence in Italian social and organizational psychology. Our understanding of this issue is that innovation tends to be favoured when there is a perception of stability and solidity regarding the context in which one is working. If the main concern is to be accepted and legitimized, it can be more difficult to explore what is not yet part of a shared practice. In our view, the question refers, once again, to the explicit and implicit rules which characterize the research arena promoting certain behavioural practices while limiting others.

\section{References}

Albanesi, C 2004, I focus group, Carocci, Roma. 
Alby, F, Zucchermaglio, C \& Baruzzo, M 2015, 'Diagnostic Decision Making in Oncology:

Creating Shared Knowledge and Managing Complexity', Mind, Culture, and Activity, vol. 1, pp. 422.

Arcidiacono, A 1999, Napoli: Diagnosi di una città, Magma, Napoli.

Arcidiacono, C \& Alfano, A 2004, Il fascino del centro antico: Napoli Firenze Berlino: risorse per la vivibilità, Magma, Napoli.

Arcidiacono, C, Grimaldi, D, Di Martino, S \& Procentese, F 2016, 'Participatory visual methods in the 'Psychology loves Porta Capuana'project'. Action research, vol. 14(4), pp. 376-392.

Arcidiacono, C, Natale, A, Carbone, A \& Procentese, F 2017, 'Participatory action research from an intercultural and critical perspective', Journal of Prevention and Intervention in the Community, vol. 1, pp. 44-56.

Barbieri, I, Zani, B \& Sonn, C 2014, 'Meanings of community in contexts of multiculture: the role of citizenship, identity, and cultural changes.', Journal of Community Psychology, vol. 8, pp. 980996.

Barello, S \& Graffigna, G 2015, 'Engaging patients to recover life projectuality: an Italian crossdisease framework', Quality of Life Research, vol. 24, pp. 1087-1096.

Benevene, P, Cortini, M \& Di Lemma, L 2014, 'Child Labor and Adolescent Labor: May They Become a Learning Opportunity?' The International Journal of Pedagogy and Curriculum, vol. 22, pp. 15-24.

Benozzo, A 2013, 'Coming out of the credenza: An Italian celebrity unveils his "new” gay self', Sexualities, vol. 16, pp. 336-360.

Benozzo, A, Koro-Ljungberg, M, Carey, N 2016, 'Post/autorship: Five or more IKEA costumers in search of an author.' Qualitative Inquiry, vol. 22, pp. 568-580.

Benozzo A, Pizzorno MC, Bell, H \& Koro-Ljungberg, M 2015, 'Coming out, but coming into what: Problematizing discursive variations in revealing the gay self in the workplace', Gender, Work and Organization, vol. 22, pp. 292-306.

Billig, M 1991, Ideology and opinions: Studies in rhetorical psychology, Sage, Thousand Oaks.

Bolger, N, Davis, A \& Rafaeli, E 2003 'Diary methods: Capturing life as it is lived', Annual Review of Psychology, vol. 54, 579-616.

Bonaiuto, M \& Fasulo, A 1998, 'Analisi della conversazione e analisi del discorso', in L Mannetti (ed.), Strategie di ricerca in psicologia sociale, Carocci, Roma, pp. 227-282.

Bosio, AC 1992, 'La ricerca sul campo: le nuove sfide', Proceedings of the VI Convegno Nazionale della Divisione di Psicologia Sociale, pp. 22-23. 
Bosio, AC 2000, 'Gli sviluppi della ricerca sociale qualitativa e le condizioni di campo dell'intervista', in G Trentini (ed.), Oltre l'intervista: il colloquio nei contesti sociali, ISEDI-UTET, Torino, pp. 341-367.

Bosio, AC \& Graffigna, G 2007, 'Quando la ricerca qualitativa diventa una professione: alcune riflessioni sull'esperienza di un master di secondo livello nell'area della ricerca qualitativa sociale e di mercato', Psicologia Sociale, vol. 3, pp. 409-416.

Bosio, AC, Graffigna, G \& Olson, K 2007, “Theory of Theory" and "Theory of Technique": two different frames for qualitative methodology. How to define and manage them in the research process?' Paper presented to the Advances in Qualitative Methods Conference, Banff, 21-24 September.

Braun, V \& Clarke, V 2006, 'Using thematic analysis in psychology', Qualitative research in psychology, vol. 3, pp. 77-101.

Brondi, S, Sarrica, M, Caramis, A, Piccolo, C \& Mazzara BM 2016, 'Italian parliamentary debates on energy sustainability: How argumentative "short-circuits" affect public engagement', Public Understanding of Science, vol. 6, pp. 737-753.

Bruni, A \& Gobo, A 2005, 'Qualitative research in Italy', Forum: Qualitative Social Research, vol. 6, pp. 1-21.

Bruno, A \& Dell'Aversana, G 2018, “What shall I pack in my suitcase?': the role of workintegrated learning in sustaining social work students' professional identity', Social Work Education, vol. 37, pp. 34-48.

Castiglioni, C, Lozza, E \& Bosio, AC 2018, 'Lay People Representations on the Common Good and Its Financial Provision', SAGE Open, 8(4), 2158244018807247.

Chamberlain, K, McGuigan, K, Anstiss, D \& Marchall, K 2018, 'A change of view: Art-based research in psychology', Qualitative Research in Psychology, vol. 15, pp. 131-139.

Chiarolanza, C \& De Gregorio, E 2007, L'analisi dei processi psico-sociali: lavorare con ATLAS. $T i$, Carocci, Roma.

Cicognani, E 2002, Psicologia sociale e ricerca qualitativa, Carocci, Roma.

Colucci, FP \& Camussi, E 1998, 'Per una teoria del senso comune nella psicologia della politica', in FP Colucci (ed.), Il cambiamento imperfetto: I cittadini, la comunicazione politica, i leader nell'Italia degli anni Novanta, Unicopli, Milano, pp. 103-138.

Colucci, FP, Colombo, M \& Montali, L (eds.) 2008, La ricerca-intervento. Il Mulino, Bologna. Colucci, FP \& Montali, L 2008 'Comparative application of two methodological approaches to the analysis of discourses', International Journal of Multiple Research Approaches, vol. 2, pp. 57-70. 
D’Angelo, C, Reverberi, E, Gazzaroli, D \& Gozzoli, C. 2017, 'At the end of the match: exploring retirement of Italian football players', Revista de psicología del deporte, vol. 26(3), pp. 130-134 D’Aprile, G \& Mannarini, T 2010, 'Corporate social responsability: A psychosocial multidimensional construct', Journal of Global Responsability, vol. 3, pp. 48-65.

De Grada, E \& Bonaiuto, M 2002, Introduzione alla psicologia sociale discorsiva, Laterza, Bari. Denzin NK \& Lincoln YS (eds.) 1994, Handbook of qualitative research, Sage, Thousand Oaks. de Rosa, AS, Bocci, E \& Dryjanska, L 2017, 'Social representations of the European capitals and destination e-branding via multi-channel web communication', Journal of Destination Marketing \& Management, doi: https://doi.org/10.1016/j.jdmm.2017.05.004.

De Simone, S, Lasio, D, Onnis, D \& Putzu, D 2017, 'Inequality or Equality? Discursive Constructions of Gender Gap in Politics', Polis, 31(2), pp. 177-206.

De Simone, S \& Scano, C 2017, 'Discourses of sameness, unbalance and influence: dominant gender order in medicine', Journal of Gender Studies, DOI: 10.1080/09589236.2017.1357541. Di Fabio, A 2016, 'Life design and career counseling innovative outcomes', The Career Development Quarterly, vol. 64(1), pp. 35-48.

Edwards, D \& Potter, J 1992, Discursive psychology, Sage, London.

Everri, M, Fruggeri, L \& Molinari, L 2014, 'Microtransitions and the dynamics of family functioning', Integrative Psychological and Behavioral Science, vol. 48(1), pp. 61-78.

Fairclough, N 2001, 'Critical discourse analysis as a method in social scientific research', in R Wodak and M Meyer, (ed.), Methods of Critical Discourse Analysis, Sage, London, pp. 121-138. Fatigante, M, Alby, F, Zucchermaglio, C \& Baruzzo, M 2016, 'Formulating treatment recommendation as a logical consequence of the diagnosis in post-surgical oncological visits', Patient education and counseling, vol. 99(6), pp. 878-887.

Fedi, A, Colombo, L, Bertola, L \& Rollero, C 2017, 'Women and career between gender stereotypes and work family roles. A psychosocial analysis', Sociologia del lavoro, vol. 148, pp.113-133.

Ferrarotti, F 1989, La sociologia alla riscoperta della qualità, Laterza, Bari. Frigerio, A \& Montali, L 2016, 'An ethnographic-discursive approach to parental self-help groups: The case of ADHD', Qualitative Health Research, vol. 26(7), pp. 935-950.

Frigerio, A, Montali, L \& Fine, M 2013, 'Attention deficit/hyperactivity disorder blame game: A study on the positioning of professionals, teachers and parents', Health: An Interdisciplinary Journal for the Social Study of Health, Illness and Medicine, vol. 6, pp. 584-604.

Gattino, S \& Miglietta, A 2013, 'The looking glass. From the citizen to the migrant in Italians' naïve imagery', Journal of language and Politics, vol. 12, pp. 272-294. 
Gilardi, S, Guglielmetti, C, Casati, S \& Monti, P 2014, 'Promuovere l'engagement dei pazienti con malattie croniche: Un percorso di ricerca collaborativa', Psicologia della salute, vol. 3, pp. 58-79. Gilardi, S, Guglielmetti, C \& Pravettoni, G 2014, 'Interprofessional team dynamics and information flow management in emergency departments', Journal of advanced nursing, vol. 70, pp. 1299-1309. Gozzoli C, Gazzaroli D, \& D’Angelo C 2018, 'Who Cares for Those Who Take Care? Risks and Resources of Work in Care Homes', Frontiers in psychology, vol. 9, 314.

Hochdorn, A, Faleiros, VP, Camargo, BV \& Cottone, PF 2016, 'Talking gender: how (con) text shapes gender-The discursive positioning of transgender people in prison, work and private settings', International Journal of Transgenderism, vol. 17(3-4), pp. 212-229. Jaques, E 1951, The changing culture of a factory: A study of authority and participation in an industrial setting, Tavistock, London.

Jessel, J \& Ingvarsson, ET (2016). 'Recent advances in applied research on DRO procedures'. Journal of applied behavior analysis, vol. 49(4), 991-995.

Kaës, R 1968, Images de la culture chez les ouvriers français, Cujas, Paris.

Kaneklin, C 1990, 'Lo sviluppo della ricerca intervento in Italia', in E Scabini (ed.), Conoscere per intervenire. La ricerca finalizzata sulla famiglia, Vita e Pensiero, Milano.

Kidd, SA 2002, 'The role of qualitative research in psychological journals', Psychological methods, vol. 7, pp. 126-138.

Kressel, NJ \& Kressel, SW 2016, 'Trends in the Psychological Study of Contemporary Antisemitism: Conceptual Issues and Empirical Evidence', Basic and Applied Social Psychology, vol. 2, pp. 111-126.

Leone, G, Di Murro, F \& Crescenzi, LS 2015, 'From Personalization to Parrhesia: A Multimodal Analysis of Autobiographical Recalls in Barack Obama's Political Speech', Conflict and Multimodal Communication, Springer, Cham, pp. 393-374.

Liberati, EG, Gorli, M, Moja, L, Galuppo, L, Ripamonti, S \& Scaratti, G 2015, 'Exploring the practice of patient centered care: The role of ethnography and reflexivity', Social science \& medicine, vol. 133, pp. 45-52.

Losito, G 1996, L'analisi del contenuto nella ricerca sociale, FrancoAngeli, Milano.

Lozza, E, Cinelli, M and De Rosa, P 2017, 'The relationship between tax payer and tax officer: How to build trust in a tax compliance perspective', Psicologia sociale, vol. 12, pp. 197-214. Lucidi, F, Alivernini, F \& Pedon, A 2008, Metodologia della ricerca qualitativa, Il Mulino, Bologna.

Mannarini, T \& Fedi, A 2009, 'Multiple sense of community: The experience and meaning of community', Journal of Community Psychology, vol. 37, pp. 211-227. 
Mannarini, T \& Fedi, A 2012, 'Persisting or withdrawing? An insight into the psychosocial processes underlying sustained engagement', Journal of Community \& Applied Social Psychology, vol. 22(4), pp. 300-315.

Mannarini, T \& Rochira, A 2014, “"Does Community Make Any Sense?” A Semantic Analysis of the Term "Community” Among Albanian Immigrants and Italian Majority Residents', Europe's Journal of Psychology, vol. 10(4), pp. 672-693.

Mannarini, T \& Procentese, F 2018, 'Identity and Immigrant Stereotypes: A Study Based on the Ego-Ecological Approach', Identity, 18(2), pp. 77-93.

Mannetti, L (ed.) 1998, Strategie di ricerca in psicologia sociale, Carocci, Roma.

Mantovani, G 1998, L'elefante invisibile: Tra negoziazione e affermazione delle diversità-Scontri e incontri multiculturali, Giunti, Firenze.

Mantovani, G 2008, Analisi del discorso e contesto sociale: teorie, metodi e applicazioni, Il Mulino, Bologna.

Manuti, A, Scardigno, R \& Mininni, G 2017 'Diatexts at work.', Qualitative Research Journal, vol. 4, pp. 319-334.

Marzana, D, Fasanelli, R, Mercuri, F \& Fattori, F 2016, 'The Relation Between Participatory Social Practices and Social Representations of Citizenship in Young Adulthood', VOLUNTAS:

International Journal of Voluntary and Nonprofit Organizations, vol. 3, pp. 1152-1170.

Mazzara, BM 2002, Metodi qualitativi in psicologia sociale: prospettive teoriche e strumenti operativi, Carocci, Roma.

Mazzoni, D, Cornet, A, van Leeuw, B, Myllys, K \& Cicognani, E 2018, 'Living with systemic lupus erythematosus: A patient engagement perspective', Musculoskeletal care, 16(1), pp. 67-73. Mazzoni, D \& Cicognani, E 2013, 'Water as a commons: An exploratory study on the motives for collective action among Italian water movement activists', Journal of Community \& Applied Social Psychology, vol. 23(4), 314-330.

Menichetti, J \& Graffigna, G 2016, 'How older citizens engage in their health promotion: a qualitative research-driven taxonomy of experiences and meanings', BMJ open 6.7 (2016): e010402.

Mininni, G 2003, Il discorso come forma di vita, Guida, Napoli.

Montali, L, Riva, P, Frigerio, A \& Mele, S 2013, 'The representation of migrants in the Italian press: A study on the Corriere della Sera (1992-2009)', Journal of Language and Politics, vol. 12(2), pp. 226-250. 
Nencini, A, Sarrica, M, Cancian, R \& Contarello, A 2014, 'Pain as social representation: a study with Italian health professionals involved in the 'Hospital and District without Pain' project', Health promotion international, vol. 30(4), pp. 919-928.

Nicolini, D, Gherardi, S \& Yanow, D (eds.) 2003, Knowing in organizations: a practice-based approach, Routledge, NY.

Panari, C, Levati, W, Alfieri, E, Tonelli, M, Bonini, A \& Artioli, G 2015, 'La mappatura del ruolo come nuovo approccio di lettura di due professionisti ospedalieri: l'infermiere e l'operatore sociosanitario', Mecosan, 94, pp. 67-95.

Piccardo, C \& Benozzo, A 1996, Etnografia organizzativa: una proposta di metodo per l'analisi delle organizzazioni come culture, Raffaello Cortina, Milano.

Pizzorno MC, Benozzo A \& Carey N 2015, 'Narrating career, positioning identity and constructing gender in an Italian adolescent's personal narrative', Journal of Vocational Behavior, vol. 88, pp. 195-204.

Pizzorno MC, Benozzo A, Fina A, Sabato S \& Scopesi M. 2014, 'Parent-child career construction: A narrative study from a gender perspective', Journal of Vocational Behavior, vol. 84, pp. 420-430. Pola, LG, Sarrica, M \& Contarello, A 2015, 'Entrepreneurs of identity at Palazzo Marino.

Citizenship and values in the settlement speeches delivered by the Mayors of Milan since the postwar period until today’, Psicologia sociale, vol. 10(3), pp. 223-256.

Potter, J \& Hepburn, A (2005). 'Qualitative interviews in psychology: Problems and possibilities', Qualitative research in Psychology, vol. 2, 281-307.

Prati, G, Albanesi, C, Pietrantoni, L \& Airoldi, L 2016, 'Public perceptions of beach nourishment and conflict management strategies: A case study of Portonovo Bay in the Adriatic Italian Coast', Land Use Policy, vol. 50, pp. 422-428.

Rania, N, Migliorini, L, Rebora, S \& Cardinali, P 2015, 'Photovoice and Interpretation of Pictures in a Group Discussion: A Community Psychology Approach', Qualitative Research in Psychology, vol. 4, pp. 382-396.

Ricolfi, L 1997, La ricerca qualitativa, Carocci, Roma.

Ripamonti, S, Galuppo, L, Gorli, M, Scaratti, G \& Cunliffe, A 2015, 'Pushing Action Research Toward Reflexive Practice', Journal of Management Inquiry, vol. 25(1), pp. 55-68.

Ripamonti, SC \& Galuppo, L 2016, 'Work transformation following the implementation of an ERP system: An activity-theoretical perspective', Journal of Workplace Learning, vol. 28(4), pp.206223. 
Ripamonti, SC, Galuppo, L, Bruno, A, Ivaldi, S \& Scaratti, G 2018, 'Reconstructing the internship program as a critical reflexive practice: the role of tutorship', Teaching in Higher Education, pp.118.

Rizzoli, V, Romaioli, D \& Contarello, A 2017, 'The crisis tsunami. Social representations of the economic crisis in the Italian press', International Review of Social Psychology, vol. 30(1), pp. 8091.

Saks, AM \& Ashforth, BE 1997. 'Organizational socialization: Making sense of the past and present as a prologue for the future', Journal of vocational Behavior, vol. 51(2), pp. 234-279. Sarrica, M, Roseti, A, Brondi, S, Cervelli, P, \& Leone, G 2016, 'Flooded by a wall of water: parent-child reminiscing about local environment and unwanted changes', Qualitative Research in Psychology, vol. 13(3), pp. 209-230.

Scaratti, G \& Regalia, C 2000, ‘Approcci metodologici alla valutazione dei Servizi’, in C Regalia \& G Scaratti, (ed.), Valutazione e qualità nei servizi, Unicopli, Milano, pp. 43- 84.

Scaratti G, Gorli, M, Galuppo L, Ripamonti S \& Cortese, CG 2014, 'Using artifacts for practices tuning and performance refining. The Nursing Record artifact between affordance and agency: A case study', Bollettino di Psicologia Applicata, vol. 62(270), pp. 12-26.

Smith, JA \& Osborn, M 2004, 'Interpretative phenomenological analysis', in GM Breakwell (ed.), Doing social psychology research, British Psychological Society and Blackwell Publishing, Leicester/Malden, pp. 229-254.

Stephenson, N \& Kippax, S 2008, 'Memory work', in C Willig \& W Staiton-Rogers (eds.), The Sage handbook od qualitative research in psychology, Sage, London, pp. 127-146.

St. Pierre, EA 2018, 'Post Qualitative Inquiry in an Ontology of Immanence', Qualitative Inquiry, DOI 1077800418772634.

Tamanza, G, Gozzoli, C \& Gennari, M 2016, 'Revealing the difference: Between conflict mediation and law enforcement. Living and working together as a conceptual and methodological turning point to activate transformation in a juvenile criminal mediation service', World Futures, vol. 72(56), pp. 234-253.

Testoni, I, Ghellar, T, Rodelli, M, De Cataldo, L \& Zamperini, A 2017, 'Representations of death among Italian vegetarians: an ethnographic research on environment, disgust and transcendence', Europe's journal of psychology, vol. 13(3), pp. 378-395.

Trentini, G (ed.) 1996, Manuale del colloquio e dell'intervista. UTET, Torino.

World Economic Forum 2017, The Global Gender Gap Report, available from: http://www3.weforum.org/docs/WEF_GGGR_2017.pdf [1 June 2018].

Zammuner, VL 2003, I focus group, Il Mulino, Bologna. 
Zamperini, A \& Mascena, A 2017, ‘Study like Italians do’as a migration project: field research in Togo', Ethnography and Education, vol. 12(3), pp. 271-293.

Zamperini, A, Testoni, I, Primo, D, Prandelli, M \& Monti, C 2016, 'Because moms say so:

Narratives of lesbian mothers in Italy', Journal of GLBT Family Studies, vol. 12(1), pp. 91-110.

Zucchermaglio, C 1991, Gli apprendisti della lingua scritta, Il Mulino, Bologna.

Zucchermaglio, C 2000, 'Gruppi di lavoro, tecnologie, pratiche sociali e negoziazione', in G

Mantovani (ed.), Ergonomia. Lavoro, sicurezza e nuove tecnologie, Il Mulino, Bologna, pp. 181202.

Zucchermaglio, C 2002, Psicologia culturale dei gruppi, Carocci, Roma.

Zucchermaglio, C \& Alby, F 2017, 'Social Interactions and Cultural Repertoires as Resources for Coping With Breast Cancer', SAGE Open, vol. 7(1), pp. 1-9. 